\title{
The Serological Grouping of Streptococcus equinus
}

\author{
By D. G. SMITH AND P. M. FRANCES SHATTOCK \\ Department of Microbiology, University of Reading
}

(Received 28 May 1962)

\begin{abstract}
SUMMARY
Streptococci isolated from horse faeces and corresponding to the description of Streptococcus equinus Andrewes \& Horder (1906) were found to belong to the serological group $\mathbf{D}$. The group $\mathbf{D}$ antigen was produced by all the strains examined, but was not always extractable from whole organisms by $\mathrm{HCl}$ or formamide; broken organisms, however, always gave group $\mathbf{D}$ antigen. Collections of $S$. equinus and $S$. bovis strains were found to be physiologically similar, but distinguishable.
\end{abstract}

\section{INTRODUCTION}

Andrewes \& Horder (1906) first described Streptococcus equinus as the predominant streptococcus of horse faeces. A fuller description was given by Hodge \& Sherman (1937; see Table 1 ). The serology of $S$. equinus has received little attention. According to Bergey's Manual (1957) 'no group-specific antigen has been demonstrated'. However, Sherman (1938) reported that some of his strains of $S$. equinus 'reacted weakly' with group $D$ antiserum and there have also been recent reports of $S$. equinus strains reacting with group D antisera (e.g. Fuller et al. 1960; Raibaud, Caulet, Galpin \& Mocquot, 1961). These observations are substantiated by our present findings with 50 strains of $S$. equinus isolated from horse faeces. Because $S$. equinus is similar in many respects to $S$. bovis, which also belongs to serological group D (Shattock, 1949), the physiological reactions of the two species were compared.

\section{METHODS}

Organisms. Thirty-six strains of streptococci which did not ferment lactose and had been isolated at various times from faeces of nine horses in the same stable, and fourteen similar isolates supplied by Professor H. W. Seeley (Cornell University) were examined. They all conformed to the descriptions of Streptococcus equinus given by Andrewes \& Horder (1906) and Hodge \& Sherman (1937). The $S$. bovis strains used were from the collection in this laboratory.

\section{Physiological tests}

The nutrient medium for growing organisms for physiological tests and for serological investigations was glucose Lemco broth $(\%, w / v:$ Evans peptone, 1; Lab. Lemco, 1; NaCl, 0.5; glucose, 0.5). The temperature of incubation was $37^{\circ}$. For physiological tests the inoculum was one loopful $(4.0 \mathrm{~mm}$. diam.) of an $18 \mathrm{hr}$. culture.

Sugar reactions. Tubes of peptone water $(1 \% ; 5 \mathrm{ml}$.$) containing 0.5-1 \%$ of the 
test sugar and bromocresol purple as indicator were inoculated and examined daily for 10 days.

Litmus milk was examined daily for 10 days.

Starch hydrolysis. Starch $(0 \cdot 3 \%)$ nutrient agar plates were streaked with organism and after incubation for 2-3 days flooded with Gram's iodine. A colourless or light brown zone under and around the area of growth was recorded as positive.

Ammonia from arginine. Arginine $(0.3 \%)$ broth was examined with Nessler's reagent for the presence of ammonia after 3-4 days.

Tolerance of potassium tellurite. Streaked plates of glucose nutrient agar containing potassium tellurite $(0.04 \%)$ were examined after $24 \mathrm{hr}$. Tolerant streptococci (Streptococcus faecalis) grow profusely as black colonies. No growth or a dusty grey growth of small colonies was recorded as negative.

Groroth on bile blood agar. Glucose yeast-extract nutrient agar containing $\mathbf{4 0} \%$ $(\mathrm{v} / \mathrm{v})$ Difco Bacto oxgall and $5 \%(\mathrm{v} / \mathrm{v})$ horse blood was streaked and the plates examined after incubation for $48 \mathrm{hr}$.

Growth in presence of $\mathbf{2 . 0} \%$ and $\mathbf{6 . 5} \% \mathrm{NaCl}$. Glucose Lemco broth containing $2.0 \%$ or $6.5 \% \mathrm{NaCl}$ (Analar) was inoculated and examined after $24 \mathrm{hr}$.

Other physiological tests were those used by Shattock (1949) and Sharpe \& Shattock (1952).

\section{Serological methods}

Preparation of group-specific antisera in rabbits. The technique of Jones \& Shattock (1960) was used.

Preparation of antigen extracts. Extracts were prepared by using $0.05 \mathrm{M}-\mathrm{HCl}$ (Lancefield, 1933), formamide (Fuller, 1938), alkali (Elliott, 1960). HCl extracts were concentrated by ethanol precipitation (Shattock, 1949).

Gel-diffusion. The method of Mansi (1958) was used. Slides bearing the gel were stored at room temperature in Petri dishes containing moist cottonwool to prevent the gel drying. Results were read after 2-3 hr. This method was compared with the plate method (Mansi, 1957) which gave similar results.

Absorption tests were made as described by Shattock (1949).

Preparation of cell walls. Cell walls were prepared by the method of Cummins \& Harris (1956) but without pepsin digestion (Jones \& Shattock, 1960).

\section{RESULTS}

The serological grouping of Streptococcus equinus

$\mathrm{HCl}$ extracts of 48 of the 50 strains of Streptococcus equinus examined gave strong precipitin reactions with group $D$ antisera; in most cases it was not necessary to concentrate the extracts by ethanol precipitation; the two apparently aberrant strains are discussed below. All the extracts tested (31) by slide gel-diffusion against group D antisera gave lines of precipitate. They also showed patterns of identity with $\mathrm{HCl}$ extracts of accepted group D strains ( $S$. faecalis $775 ; S$. durans $98 \mathrm{D}$ ).

A potent group D antiserum was prepared by using Streptococcus equinus strain $\mathrm{CNI}$ for immunization. This antiserum reacted strongly with $\mathrm{HCl}$ extracts of group D strains in the precipitin-ring test and in slide gel-diffusion tests. Patterns of identity were given by extracts of $S$. equinus strains and of other group D strains with the antiserum prepared from $S$. equinus strain $\mathrm{CN} 1$. 
The serological grouping of Streptococcus equinus strains as belonging to group D was confirmed by reciprocal absorption tests. The group D antibody in $S$. equinus strain CN 1 antiserum was completely absorbed by $S$. durans strain $98 \mathrm{D}$ organisms; similarly, $S$. equinus strain $\mathrm{CN1}$ organisms completely removed group antibody from the group D antiserum prepared with $S$. durans strain $98 \mathrm{D}$.

Jones \& Shattock (1960) showed that the group D antigen in representative strains of all species of group D streptococci examined was not located in the cell wall but was in the cell contents. Isolations of cell walls were made from two strains of Streptococcus equinus (CN1, T1). $\mathrm{HCl}$ extracts of separated cell walls gave no reaction with group $\mathrm{D}$ antisera. The cell contents fraction, however, gave a strong precipitin-ring reaction and lines of precipitate in gel-diffusion tests. The cell contents fraction acidified with $\mathrm{HCl}$ to $0.05 \mathrm{M}$, heated in a boiling-water bath for $5 \mathrm{~min}$. and neutralized, still gave strong reactions with group $\mathbf{D}$ antisera in precipitin-ring and gel-diffusion tests.

The $\mathrm{HCl}$ extract of cell walls of Streptococcus equinus strain $\mathrm{CN} 1$ reacted with the homologous antiserum, indicating that the type antigen was located in the cell wall. Thus the locations of antigens in S. equinus are similar to those in other species of group D streptococci (Elliott, 1960).

The two aberrant strains of Streptococcus equinus referred to above $(24, \mathrm{~A}, 34 \mathrm{~A}$ obtained from Professor H. W. Seeley) were indistinguishable physiologically from the rest of the group. $\mathrm{HCl}$ extracts of these strains even after ethanol concentration gave no precipitates with group $D$ antisera. Formamide extracts (Fuller, 1938) gave weak reactions in precipitin-ring and gel-diffusion tests. Because it has been shown that the group D antigen is located in the cell contents (Jones \& Shattock, 1960; Elliott, 1960) preparations of cell contents of these two aberrant strains obtained after breaking (Mickle disintegrator) the organisms were tested against group $\mathbf{D}$ antisera. Both preparations of cell contents gave strong reactions in precipitin-ring and geldiffusion tests. Moreover, the precipitates in gel-diffusion test gave patterns of identity with $\mathrm{HCl}$ extracts of group $\mathbf{D}$ species Streptococcus faecalis (strain 775) and $\boldsymbol{S}$. faecalis var. liquefaciens (strain Elv. 2025). It therefore appears that the group $D$ antigen present in these two apparently aberrant strains is not extractable from whole organisms by hydrochloric acid. Precipitin-ring reactions were, however, obtained with alkaline extracts (Elliott, 1960) of whole organisms of these two strains when tested against the same group $D$ antisera as used in the previous tests. The alkaline extract of only one of these strains (34 A) gave a line of precipitate in a gel-diffusion test and it showed a pattern of identity.

Comparison of physiological character of Streptococcus equinus and S. bovis

In many respects Streptococcus equinus resembles $S$. bovis; some workers have questioned the validity of separating the two species (Seeley \& Dain, 1960). For this reason we compared the physiological reactions of our 50 strains of $S$. equinus with 43 strains of $S$. bovis. The results are given in Table 1 where they are compared with the characters of $S$. equinus as reported by Hodge $\&$ Sherman (1937) and with 95 starch-hydrolysing streptococci conforming to the definition of $S$. bovis described by Seeley \& Dain (1960).

Streptococcus equinus characteristically does not ferment lactose; this is a character used to distinguish it from $S$. bovis, which does. Seeley \& Dain (1960) pointed out 
734

D. G. Smith and P. M. Frances Shatrock

that this is not a strong reason for separating these two species. Although other physiological reactions may not clearly distinguish between them, we feel that when the physiological reactions are viewed as a whole there is still sufficient reason for retaining the two species. Apart from the separation over lactose fermentation, most of our strains of $S$. equinus did not ferment trehalose, raffinose or inulin, nor hydrolyse

Table 1. Physiological reactions of Streptococcus equinus and $\mathbf{S}$. bovis

\begin{tabular}{|c|c|c|c|c|}
\hline & $\begin{array}{l}S . \text { equinus } \\
50 \text { cultures }\end{array}$ & $\begin{array}{l}\text { S. equinus } \\
\text { Hodge \& } \\
\text { Sherman } \\
(\mathbf{1 9 3 7}), \\
72 \text { cultures }\end{array}$ & $\begin{array}{c}S . \text { bovis, } \\
43 \text { cultures }\end{array}$ & $\begin{array}{c}\text { Starch- } \\
\text { hydrolysing } \\
\text { streptococci, } \\
\text { Seeley \& Dain } \\
\text { (1960), } \\
\text { 95 cultures }\end{array}$ \\
\hline Grow at $10^{\circ}$ & 2 & $\mathbf{0}$ & $\mathbf{0}$ & 0 \\
\hline Grow at $45^{\circ}$ & 96 & 100 & 100 & 95 \\
\hline Resist $60^{\circ}$ for $30 \mathrm{~min}$. & 2 & 14 & $\theta$ & . \\
\hline Resist $60^{\circ}$ for $15 \mathrm{~min}$. & 12 & . & . & - \\
\hline Grow at pH 9.6 & $\mathbf{0}$ & - & $\mathbf{0}$ & . \\
\hline $\mathbf{N H}_{3}$ from arginine & $\mathbf{0}$ & . & $\mathbf{0}$ & $\mathbf{3}$ \\
\hline Grow in $6.5 \% \mathrm{NaCl}$ & 0 & . & $\mathbf{0}$ & $\mathbf{0}$ \\
\hline Grow in $2.0 \% \mathrm{NaCl}$ & 94 & . & . & $99^{*}$ \\
\hline Grow on $40 \%$ bile & 100 & . & 100 & 100 \\
\hline No change in litmus milk & 100 & 100 & $\mathbf{0}$ & $\mathbf{3}$ \\
\hline Tellurite $(0.04 \%)$ tolerant & $\mathbf{0}$ & . & $\mathbf{0}$ & . \\
\hline Hydrolyse starch & $0 \dagger$ & $\mathbf{0}$ & 95 & 100 \\
\hline Hydrolyse aesculin & 90 & 100 & 100 & 99 \\
\hline Ferment: Arabinose $(\mathbf{L}+)$ & $\mathbf{9}$ & 0 & 50 & 48 \\
\hline Xylose & o & $\mathbf{0}$ & . & 0 \\
\hline Lactose & $\mathbf{0}$ & $\mathbf{0}$ & 100 & 99 \\
\hline Sucrose & 80 & 92 & 91 & 100 \\
\hline Trehalose & 12 & . & 33 & 68 \\
\hline Raffinose & 6 & 6 & 82 & 95 \\
\hline Inulin & 12 & 31 & 89 & 96 \\
\hline Mannitol & $\mathbf{0}$ & $\mathbf{0}$ & 13 & 12 \\
\hline Sorbitol & 0 & $\mathbf{0}$ & $\mathbf{0}$ & 0 \\
\hline Salicin & 100 & 88 & 98 & - \\
\hline$\beta$-Haemolysis & 0 & 0 & 0 & $6 \ddagger$ \\
\hline
\end{tabular}

$* 2.5 \% \mathrm{NaCl}$. $\dagger 60 \%$ showed slight starch hydrolysis. $\ddagger$ Under $\mathrm{CO}_{2}$.

Table 2. Sugar reactions of Streptococcus equinus and S. bovis

Sugar reaction patterns

Mannitol
Trehalose
Arabinose
Raffinose
Inulin
Sucrose

$\begin{array}{rrrrrrrrrrrrrrrr}1 & 2 & 3 & 4 & 5 & 6 & 7 & 8 & 9 & 10 & 11 & 12 & 13 & 14 & 15 & 16 \\ + & - & - & - & - & - & - & - & - & - & - & - & - & - & - & - \\ + & + & - & + & + & - & - & - & - & + & + & - & - & - & - & - \\ + & + & + & + & - & + & + & - & - & - & - & + & - & - & - & - \\ + & + & + & - & + & + & - & + & + & - & - & - & - & + & - & - \\ + & + & + & + & + & - & + & - & + & + & - & - & + & - & - & - \\ + & + & + & + & + & + & - & + & + & + & + & + & + & - & + & -\end{array}$

No. of strains showing given pattern

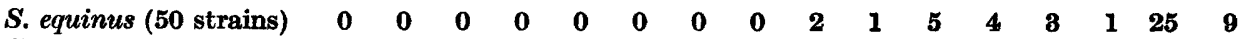

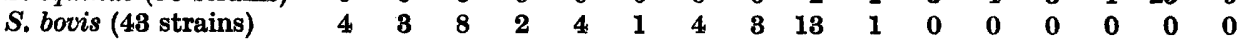
$+=$ acid reaction; $-=$ no reaction. 
starch strongly. In contrast, no strain of $S$. bovis was negative in all these tests. An analysis of the sugar reactions of our $S$. equinus and $S$. bovis strains is given in Table 2. The $S$. bovis strains are all in sugar reaction patterns 1 to 10 ; all the $S$.equinus strains fall into patterns 9 to 16. There is slight overlap of the two species in patterns 9 and 10. Dunican \& Seeley (1962) reported that when $S$. equinus hydrolysed starch this differed markedly from starch hydrolysis by $S$. bovis: $S$. equinus hydrolysed starch (but not to reducing sugar) only in the presence of an easily fermentable carbohydrate. The reaction in litmus milk is also a distinguishing character: as would be expected $S$. equinus, being unable to ferment lactose, gives no reaction in litmus milk whereas $S$. bovis produces acid, though this reaction may be slow (several days) to develop. Thus $S$. equinus and $S$. bovis form fairly distinct physiological groups. There is, however, a spectrum of physiological characters between what might be called typical members of each species. A similar picture is seen in the relationship of some other group D species, for example $S$. faecium and S. durans (Lake, Deibel \& Niven, 1957; Shattock, 1962).

A grant from the Agricultural Research Council is gratefully acknowledged.

\section{REFERENCES}

Andrewes, F. W. \& Horder, T. J. (1906). A study of the streptococci pathogenic for man. Lancet, ii, 708.

Bergey's Manual of Determinative Bacteriology (1957). 7th ed. Ed. by R. S. Breed, E. G. D. Murray \& N. R. Smith. London: Ballière, Tindall and Cox Ltd.

Cummins, C. S. \& Harris, H. (1956). The chemical composition of the cell wall in some Gram-positive bacteria and its possible value as a taxonomic character. J. gen. Microbiol. 14, 583.

Dunican, L. K. \& Seeley, H. W. (1962). Starch hydrolysis by Streptococcus equinus. J. Bact. 83, 264.

Elliott, S. D. (1960). Type and group polysaccharides of group D streptococci. J. exp. Med. 111, 621.

Fuller, A. T. (1938). The formamide method for the extraction of polysaccharides from haemolytic streptococci. Brit. J. exp. Path. 19, 130.

Fuller, R., Newland, L. G. M., Briggs, C. A. E., Braude, R. \& Mitcheld, K. G. (1960). The normal intestinal flora of the pig. IV. The effect of dietary supplements of penicillin, chlortetracycline or copper sulphate on the faecal flora. J. appl. Bact. 23, 195.

Hodge, H. M. \& Sherman, J. M. (1937). Streptococcus equinus. J. Bact. 33, 283.

Jones, D. \& Shatrock, P. M. F. (1960). The location of the group antigen of group D streptococcus. J. gen. Microbiol. 23, 335.

LAKe, D. E., Deibei, R. H. \& Niven, C. F. (1957). The identity of Streptococcusfaecium. Bact. Proc. p. 13.

LANCEFIELD, R. C. (1933). A serological differentiation of human and other groups of haemolytic streptococci. J. exp. Med. 57, 571.

Mansi, W. (1957). The study of some viruses by the plate gel diffusion precipitin test. J. comp. Path. 67, 297.

Mansi, W. (1958). Slide gel diffusion precipitin test. Nature, Lond. 181, 1289.

Raibaud, P., Caulet, M., Galpin, J. V. \& Mocquot, G. (1961). Studies on the bacterial flora of the alimentary tract of pigs. II. Streptococci: selective enumeration and differentiation of the dominant group. J. appl. Bact. 24, 285.

Seeley, H. W. \& Dain, J. A. (1960). Starch hydrolysing streptococci. J. Bact. 79, 230. 
Sharpe, M. E. \& Shattock, P. M. F. (1952). The serological typing of group D streptococci associated with outbreaks of neonatal diarrhoea. J. gen. Microbiol. 6, 150.

Shatтock, P. M. F. (1949). The streptococci of group D; the serological grouping of Streptococcus bovis and observations on serologically refractory group D strains. J. gen. Microbiol. 3, 80.

Shattock, P. M. F. (1962). Enterococci in Chemical and Biological Hazards in Foods. Ames, Iowa, U.S.A.: Iowa State University Press.

Sherman, J. M. (1938). The enterococci and related streptococci. J. Bact. 35, 81. 